[CONXRIBUTION FROM THE CHEMICAL LABORATORY OF THE UNIVERSITY OF CAIIFORNIA.]

\title{
THE VAPOR PRESSURES OF CADMIUM, LEAD AND TIN AMALGAMS.
}

By Jokl H. HuLDERRAND, A. H. Fostrar and C. W. BeEBE.

Received January 15, 1920.

The work here presented is part of a series of measurements which has been carried our during recent years upon the vapor pressures of amalgams. The previous papers give vapor-pressure measurements upon the following amalgams: zinc, ${ }^{1}$ silver, ${ }^{2}$ gold, ${ }^{2}$ bismuth, ${ }^{2}$ thallium, ${ }^{3}$ and supplement the important investigations of T.W. Richards ${ }^{4}$ and G. A. Hulett ${ }^{5}$ and their co-workers upon the electromotive forces of amalgam-concentration cells and other properties of amalgams at ordinary temperatures.

The experimental procedure was essentially the same as that used in the earlier investigations and need not be again described. The accuracy is somewhat inferior to that of earlier measurements, although the "probable error" of the average value at each concentration is less than \pm 0.001 in all cases except with the concentrated lead amalgams, where, for some unknown reason, it increased.

The results are given in Tables I, II and III, where $n$ represents the number of mols. of mercury per mol. of the other constituents, $N$ represents the mol-fraction of mercury (equal to $n /(n+1) ; p$ the vapor pressure of mercury over the amalgam of composition $N$, and $p_{0}$ that of pure mer" cury at the same temperature.

The calculated values were obtained by the aid of the equation:

$$
\log p / p_{0}=\log N+a /(x+c n)^{2}
$$

using the following values of $a$ and $c$ :

\begin{tabular}{|c|c|c|c|}
\hline & Cd-amalgams. & Pbamalgams & Sn-amalgams \\
\hline$\ldots \ldots$ & - & +0.252 & +0.220 \\
\hline . & +1.90 & $+0.3 I$ & +0.26 \\
\hline
\end{tabular}

This equation is to be regarded simply as an empirical expression for smoothing vapor-pressure data, as was done in the earlier papers of this series.

The results are also expressed graphically by the curves in the figure. It will be noted that the vapor pressures of cadmium amalgams are less than are demanded by Raoult's law, $p / p_{0}=N$, and that the deviation becomes much greater at high concentrations of cadmium. Tin and lead

${ }^{1} \mathrm{~J}$. H. Hildebrand, Orig. Comm. 8th Inter. Cong. Appl. Chem., 22, 139, I47; Trans. Am. Electrochem. Soc., 22, 319, 335 (1912); This JourNaI, 35, 501 (1913).

${ }^{2}$ Ermon D. Eastman and J. H. Hildebrand, ThIs Journal, 36, 2020 (I9I4).

${ }^{8}$ Ibid., 37, 2452 (1915).

- Carnegie Inst. Pub., 56, 118; Z. physik. Chem., 58, 683 (1907); 72, 129, 165 (x909); This JoURNAL, 4I, I732 (1919).

s'Teis Journal, 30, 1812 (1908); J. Phys. Chem, 14, 158 (1910). 
atnalgams at $324^{\circ}$ show almost identical deviations from Raoult's law, just as they do at ordinary temperatures, as seen from the e. m. f. measurements of Richards and Garrod-Thomas.

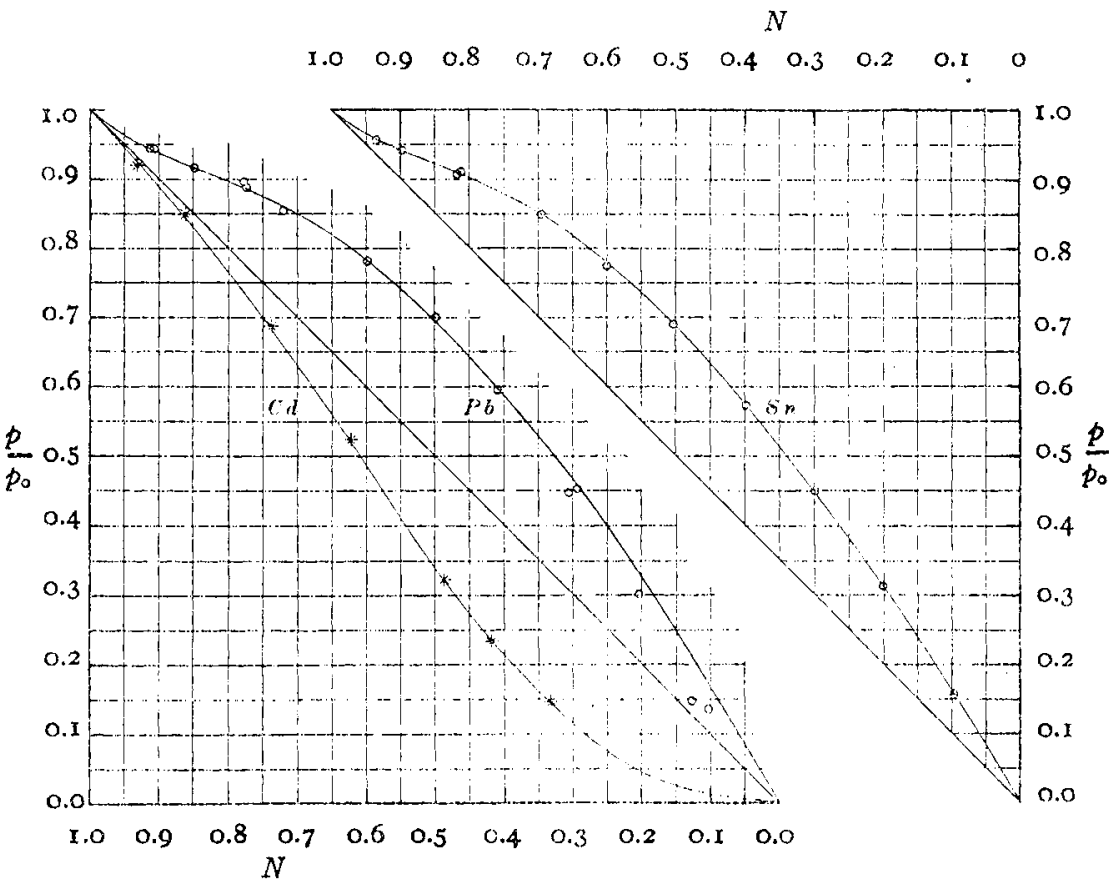

The values for lead amalgams of high lead content are very unsatisfactory, so far as consistence is concerned, and, from theoretical considerations, are doubtless too low. It is extremely improbable that the curve contains any inflection at the lower end, as the measurements would seem to demand. There is no other case known to us in all the literature on vapor pressure where such behavior is indicated. More careful investigation of this region was prevented by the entrance of all of us into war service, and it has not since seemed worth while to hold up the publication of these results for the experimental work it would require.

\begin{tabular}{|c|c|c|c|c|c|c|c|}
\hline \multirow{2}{*}{$\begin{array}{c}\text { Wt. Cd. } \\
\text { G. }\end{array}$} & \multirow{2}{*}{$\begin{array}{l}\text { Wt. }{ }_{\text {G. }} \text {. } \\
\text {. }\end{array}$} & \multicolumn{2}{|c|}{ TABLE I.-CaDMIUM } & \multirow{2}{*}{$\begin{array}{l}\text { Number } \\
\text { of obs. }\end{array}$} & AT $322^{\circ}$. & $p / p_{0}$. & \multirow[b]{2}{*}{ Calc.(2). } \\
\hline & & $n$. & $N$. & & Obs. & Caic. (1). & \\
\hline 1.046 & 25.23 & $13.5 \mathrm{I}$ & 0.931 & 6 & 0.920 & 0.927 & 0.928 \\
\hline 2.050 & $22.6 \mathrm{I}$ & 6.19 & 0.861 & 5 & 0.850 & 0.845 & 0.847 \\
\hline 4.752 & 23.90 & 2.815 & 0.738 & 6 & 0.688 & 0.680 & 0.682 \\
\hline 7.034 & 20.67 & I. 650 & 0.623 & 6 & 0.525 & 0.522 & 0.513 \\
\hline 8.874 & 15.10 & 0.953 & 0.488 & 5 & 0.322 & 0.323 & 0.317 \\
\hline 8.879 & II. 36 & 0.720 & 0.418 & 6 & 0.232 & 0.235 & 0.235 \\
\hline$x 0.08$ & 8.90 & 0.495 & 0.331 & 6 & 0.148 & 0.148 & 0.154 \\
\hline
\end{tabular}


TABLE, II.-I,EAD AMalgams a $324^{\circ}$.

\begin{tabular}{|c|c|c|c|c|c|c|}
\hline \multirow{2}{*}{$\begin{array}{l}\text { Wt. Pb. } \\
\text { G. }\end{array}$} & \multirow{2}{*}{$\begin{array}{l}\text { Wt. Hg. } \\
\text { G. }\end{array}$} & \multirow[b]{2}{*}{$n$} & \multirow[b]{2}{*}{$N}$. & \multirow{2}{*}{$\begin{array}{l}\text { Number } \\
\text { of obs. }\end{array}$} & \multicolumn{2}{|c|}{$p / p_{0}$} \\
\hline & & & & & Obs. & Calc. \\
\hline 1. 155 & II. 67 & Io. 43 & 0.912 & 4 & 0.944 & 0.943 \\
\hline 2.240 & 11.77 & 9.80 & 0.907 & 5 & 0.944 & 0.938 \\
\hline 1.734 & $9.35^{8}$ & 5.56 & 0.848 & 5 & 0.915 & 0.918 \\
\hline 3.005 & II.II & $3.4^{8}$ & 0.777 & 5 & 0.897 & 0.887 \\
\hline 3.026 & 9.990 & $3.4^{2}$ & 0.774 & 8 & 0.887 & 0.8856 \\
\hline 2.590 & $6.44^{\circ}$ & 2.57 & 0.720 & 7 & 0.855 & $0.86 x$ \\
\hline 4.449 & 6.432 & $x .492$ & 0.599 & 6 & 0.782 & 0.784 \\
\hline 5.603 & 5.350 & 0.987 & 0.497 & 9 & 0.700 & 0.698 \\
\hline 6.880 & $4.55^{8}$ & 0.820 & 0.4 .07 & 7 & 0.597 & 0.590 \\
\hline 8.059 & 3.426 & $0.44^{\circ}$ & 0.305 & 6 & $(0.448)^{a}$ & 0.478 \\
\hline 8.037 & 3.210 & 0.412 & 0.292 & 4 & $(0.452)$ & 0.461 \\
\hline 9.652 & $2 \cdot 342$ & $0.25 I$ & $0.20 \mathrm{r}$ & 9 & $(0.302)$ & $0.33 x$ \\
\hline 7.846 & I. .087 & 0.1513 & 0.125 & 9 & $(0.849)$ & $0.2 \times 2$ \\
\hline 10.518 & I. 145 & 0.1122 & 0.101 & 4 & $(0,137)$ & 0.174 \\
\hline
\end{tabular}

"The values in parentheses are regarded as inaccurate.

TABLE III.-Trin Amalgams, at $324^{\circ}$

\begin{tabular}{|c|c|c|c|c|c|c|}
\hline \multirow{2}{*}{$\begin{array}{l}\text { Wt. Sn. } \\
\text { G. }\end{array}$} & \multirow{2}{*}{ Wt. $\mathrm{Hg}}$. & \multirow[b]{2}{*}{$n}$. & \multirow[b]{2}{*}{$N$} & \multirow{2}{*}{$\begin{array}{l}\text { Number } \\
\text { of obs. }\end{array}$} & \multicolumn{2}{|c|}{$p / p_{0}}$. \\
\hline & & & & & Obs. & Calc. \\
\hline 0.6166 & 15.33 & $\mathrm{x} 4.68$ & 0.936 & 5 & 0.958 & 0.959 \\
\hline$x .224$ & 18.59 & 9.00 & 0.900 & 7 & 0.944 & 0.944 \\
\hline 1.224 & 18.46 & 8.93 & 0.899 & 5 & 0.943 & 0.942 \\
\hline 2.510 & $x 9 . x 2$ & $4.5 I$ & 0.818 & 6 & 0.908 & 0.912 \\
\hline $2.5 \mathrm{OI}$ & 19.25 & 4.300 & $0.8 \pi$ & 5 & 0.911 & 0.908 \\
\hline 3.322 & 13.00 & $2.28 \pi$ & 0.695 & 5 & 0.850 & 0.849 \\
\hline 4.739 & 12.03 & 1.500 & 0.600 & 5 & 0.777 & 0.780 \\
\hline 5.234 & 8.930 & 1.007 & 0.502 & 6 & 0.690 & 0.690 \\
\hline 5.235 & 5.846 & 0.660 & 0.398 & 6 & 0.574 & 0.575 \\
\hline 5.742 & 4.138 & 0.428 & 0.299 & 8 & 0.450 & $0.45 \pi$ \\
\hline 6.904 & 2.915 & 0.250 & 0.200 & 7 & 0.313 & 0.312 \\
\hline $8.85 \mathrm{I}$ & I.65I & 0.1103 & 0.099 & 4 & 0.159 & 0.160 \\
\hline
\end{tabular}

The values for cadmium amalgams can be reproduced very closely by assuming partial solvation, according to the equation:

$$
\mathrm{Cd}+\mathrm{Hg}=\mathrm{CdHg}
$$

as was done in a previous paper, ${ }^{1}$ for the sake of calculating the $\mathrm{e}, \mathrm{m} . \mathrm{f}$. of cadmium amalgam concentration cells.

The formula there given was

$$
\frac{p}{p_{0}}=\frac{n-1+\sqrt{(n+1)^{2}-4 B n}}{n+1+\sqrt{(n+1)^{2}-4 B n}}
$$

where $B$ is a constant which is a function of the equilibrium constant for the above reaction. The values in the last column of Table I, designated "calc. (2)," have been calculated using this formula, assigning to $B$ the

${ }^{1} \mathrm{~J}$. H. Hildebrand, "The Constitution of Cettain Iiquid Amalgams," THrs JouRNAL, 35, 50I (19I3). 
value 0.75 , which does not differ greatly from the value 0.667 , used to calculate the e. m. f. values of Richards and Forbes and of Hulett and DeItury ${ }^{1}$ at $25^{\circ}$. The behavior of cadmium amalgams may, therefore, be explained on the basis of the formation of a new molecular species without assuming the failure of Raoult's law.

This cannot so easily be done, however, in the cases of lead and tin amalgams, for the deviations from Raoult's law are here so great that they could be accounted for only by the assumption of molecules of lead and tin more complex than $\mathrm{Pb}_{2}$ and $\mathrm{Sn}_{2}$, and even curves so calculated would not correspond at all well to the actual curves. ${ }^{2}$

A theoretical discussion of all the data on amalgams obtained in this series of investigations will be the subject of a future communication.

\section{Summary.}

I. Vapor pressures of mercury over amalgams of cadmium, lead and tin at $324^{\circ}$ have been measured at intervals covering the entire range of concentrations.

2. The values of the constants in an empirical equation relating vapor pressure to composition are given for each amalagam.

3. Cadmium amalgams gave vapor pressures less than Raoult's law demands, and the deviations can be calculated on the assumption of partial solvation, varying with the concentration according to the mass law, to form molecules of $\mathrm{CdHg}$.

4. Lead and tin amalgams give vapor pressures which are nearly equal, and are much greater than Raoult's law demands. The deviations cannot be accounted for by assumption of any simple molectlar change.

BEREELEX, CAL.

\section{NOTE.}

Correction.-In the paper on "The Genesis of Petroleum as Revealed by its Nitrogen Constituents," in the October, 1919, number of Turs JourNal, p. I692, on line 32, the words "methyl chinolines" should read alkyl chinolines, and on p. 1694, on line 35 , the words "I2 kg." should read $3 \mathrm{~kg}$.

C. F. MABERY.

\section{${ }^{1}$ Loc. cit.}

${ }^{2}$ See discussion of bismuth amalgants, loc. cit. 